\title{
Bioactive Hydrogel Substrates: Probing Leukocyte Receptor-Ligand Interactions in Parallel Plate Flow Chamber Studies
}

\author{
Lakeshia J. Taite, ${ }^{1}$ Maude L. Rowland, ${ }^{1}$ Katie A. Ruffino, ${ }^{1}$ Bryan R. E. Smith, ${ }^{2}$ Michael \\ B. LAWRENCE, ${ }^{2}$ and JeNNIFER L. West ${ }^{1}$ \\ ${ }^{1}$ Department of Bioengineering, Rice University, 6100 Main Street, MS 142, Houston, TX, 77005, USA; and ${ }^{2}$ Department of \\ Biomedical EngineeringUniversity of Virginia, Charlottesville, VA, USA
}

(Received 8 March 2006; accepted 2 August 2006; published online: 10 October 2006)

\begin{abstract}
The binding of activated integrins on the surface of leukocytes facilitates the adhesion of leukocytes to vascular endothelium during inflammation. Interactions between selectins and their ligands mediate rolling, and are believed to play an important role in leukocyte adhesion, though the minimal recognition motif required for physiologic interactions is not known. We have developed a novel system using poly(ethylene glycol) (PEG) hydrogels modified with either integrin-binding peptide sequences or the selectin ligand sialyl Lewis $\mathrm{X}\left(\mathrm{SLe}^{\mathrm{X}}\right)$ within a parallel plate flow chamber to examine the dynamics of leukocyte adhesion to specific ligands. The adhesive peptide sequences arginineglycine-aspartic acid-serine (RGDS) and leucine-aspartic acid-valine (LDV) as well as sialyl Lewis $\mathrm{X}$ were bound to the surface of photopolymerized PEG diacrylate hydrogels. Leukocytes perfused over these gels in a parallel plate flow chamber at physiological shear rates demonstrate both rolling and firm adhesion, depending on the identity and concentration of ligand bound to the hydrogel substrate. This new system provides a unique polymer-based model for the study of interactions between leukocytes and endothelium as well as a platform to develop improved scaffolds for cardiovascular tissue engineering.
\end{abstract}

Keywords-Poly(ethylene glycol), Hydrogel, Leukocyte adhesion, Flow chamber.

\section{INTRODUCTION}

Leukocyte adhesion to sites of inflammation is crucial to eliminate the cause of irritation and repair the surrounding tissue. After the initiation of inflammation by cytokines such as interleukin-1 $\beta$ (IL-1 $\beta$ ), tumor necrosis factor- $\alpha$ (TNF- $\alpha$ ), lipopolysaccharide, and interleukin-3, (IL-3), leukocyte velocity slows dramatically due to leukocyte contact with the vascular wall. ${ }^{9,27,34}$ Rolling, the initial transient interaction, is mediated by selectin molecules present on the activated

Address correspondence to Jennifer L. West, 6100 Main Street, MS 142, Houston, TX, 77005, USA. Electronic mail: jwest@ rice.edu endothelial cell surface. E-selectin is an inducible surface glycoprotein that is known to bind the carbohydrate ligand sialyl Lewis $\mathrm{X}\left(\mathrm{SLe}^{\mathrm{X}}\right)$, which is present on various leukocytes ${ }^{10,11,13,35,41,43}$ and mediates stronger adhesions and slower rolling than P- or L-selectin. ${ }^{27}$ Following this primary contact, firm adhesion takes place via activated $\beta_{2}$-integrins binding intracellular adhesion molecule-1 (ICAM-1) expressed on the endothelium, and through the most important member of the $\beta_{1}$ integrin subfamily, very late antigen-4 (VLA$\left.4 ; \alpha_{4} \beta_{1}\right)$. VLA-4 binds vascular cell adhesion molecule1 (VCAM-1), and is responsible for lymphocyte adhesion to vascular endothelium and leukocyte recruitment to the inflamed area. ${ }^{1,10,11,27}$ Though well studied, the exact mechanism of adhesion to the vascular endothelium is not known. There are two suggested mechanisms of integrin activation; one proposing that activation is a result of chemokine stimulation of leukocytes ${ }^{2,43}$ and another suggesting that selectin binding leads to integrin activation. ${ }^{12,42}$

Several systems have been developed to examine the dynamics of rolling and firm adhesion and to elucidate the exact mechanism of the binding cascade. Leukocytes isolated from human blood have been studied under static and flow conditions on activated endothelial cell monolayers as well as on cells engineered to express endothelial cell adhesion molecules., $3,28,37,40$ Polystyrene microspheres coated with adhesion ligands have also been shown to interact with stimulated cell monolayers ${ }^{17}$ and on substrates coated with selectins and other cell adhesion molecules. ${ }^{11}$ Yeast engineered to display E-selectin has been observed rolling on substrates coated with SLeX. ${ }^{2}$ Recently, poly(ethylene glycol) (PEG) has been tethered to gold surfaces to create cell resistant surfaces and spatial gradients of PEG on gold surfaces have been used to study the kinetics of static cell adhesion. ${ }^{32,33}$ While each of these systems has revealed new insight into the dynamics of 
leukocyte interactions with endothelial cell adhesion molecules, the ultimate goal must be to establish a simple, cell-free system that more closely mimics the in vivo environment.

PEG hydrogels are crosslinked hydrophilic networks that demonstrate excellent biocompatibility, being highly resistant to protein adsorption and cell adhesion, and causing minimal inflammatory responses. ${ }^{20,21,22,36}$ These highly swollen networks have similar water content and mechanical properties to soft tissues and may be engineered to contain cell adhesion peptides, growth factors, and therapeutics for localized drug delivery. $5,6,26,29,30,39,44$ PEG diacrylate hydrogels may be covalently modified with cell adhesive peptide sequences to encourage cell adhesion, spreading, and migration and the interactions of cells with these hydrogels has been extensively studied under static conditions. ${ }^{15,16,24,25,29,31,38}$ A key benefit of such materials is that the base material, PEG, is intrinsically resistant to protein adsorption, so the adhesive interactions with cells are limited to the factors that are specifically engineered into the hydrogel network. In this work we propose a novel system to study leukocyte adhesion under shear using photopolymerized PEG copolymer hydrogels. After forming thin flat PEG diacrylate base hydrogels, we are able to polymerize a layer of monoacrylate PEG-peptide (or SLe ${ }^{\mathrm{X}}$ ) to the surface, and using a parallel plate flow chamber, we can observe cell adhesion using video microscopy.

\section{MATERIALS AND METHODS}

All chemicals were purchased from Sigma-Aldrich (St. Louis, MO) unless otherwise stated.

\section{Synthesis of Polyethylene Glycol Diacrylate}

Polyethylene glycol diacrylate (PEG-DA) was synthesized by dissolving $12 \mathrm{~g}$ dry PEG (MW: 6000; Fluka, Milwaukee, WI) in $16 \mathrm{ml}$ anhydrous dichloromethane (DCM) with an equimolar amount of triethylamine and $0.72 \mathrm{~g}$ acryloyl chloride (Lancaster Synthesis, Windham, NH) added dropwise. The mixture was stirred under argon for $24 \mathrm{~h}$, washed with $2 \mathrm{M} \mathrm{K}_{2} \mathrm{CO}_{3}$, and separated into aqueous and DCM phases to remove $\mathrm{HCl}$. The DCM phase was dried with anhydrous $\mathrm{MgSO}_{4}$ (Fisher Scientific, Pittsburgh, PA), and the PEG diacrylate was then precipitated in diethyl ether, filtered, and dried under vacuum at room temperature overnight. The resulting polymer was dissolved in $N, N$-dimethylformamide- $\mathrm{d}_{7}$ and characterized via proton NMR (Avance $400 \mathrm{MHz}$; Bruker, Billerica, MA) to determine the extent of acrylation.
Synthesis of PEG Derivatives Containing Cell Adhesion Molecules

The cell adhesive peptide sequence used in this study include arginine-glycine-asparagines-serine (RGDS; American Peptide Company, Inc., Sunnyvale, CA), and a peptide containing the cell adhesive leucineasparagines-valine sequence (glycine-proline-glutamic acid-isoleucine-leucine-asparagines-valine-serinethreonine, GPEILDVST), which was synthesized using standard fluorenylmethoxycarbonyl (Fmoc) chemistry on an Applied Biosystems 431A peptide synthesizer (Foster, CA). The high affinity 4-(( $N^{\prime}-2-$ methylphenyl)ureido)-phenylacetyl-leucine-aspartic acid-valineproline (Bio1211; Commonwealth Biotechnologies, Inc., Richmond, VA) $)^{5,6}$ was also used as an alternate LDV-containing compound. The non-adhesive sequences used as negative controls were arginine-glycine-glutamic acid-serine (RGES; American Peptide Company, Inc., Sunnyvale, CA) and glycine-prolineglutamic acid-isoleucine-leucine-glutamic acid-valine-serine-threonine (GPEILEVST), also synthesized using Fmoc chemistry on a peptide synthesizer.

Peptides were conjugated to PEG monoacrylate by reaction with acryloyl-PEG- $N$-hydroxysuccinimide (PEG-NHS; MW 3400; Nektar Therapeutics, Huntsville, $\mathrm{AL})$ in $50 \mathrm{mM}$ sodium bicarbonate $(\mathrm{pH} 8.5)$ at a 1:1 molar ratio for $2 \mathrm{~h}$. The mixture was then dialyzed (MWCO 1000), lyophilized, and stored at $-20^{\circ} \mathrm{C}$. Gel permeation chromatography with UV and evaporative light scattering detectors (Polymer Laboratories, Amherst, MA) was used to determine the coupling efficiency.

The selectin ligand sialyl Lewis $\mathrm{X}\left(\mathrm{SLe}^{\mathrm{X}}\right)$ was conjugated to PEG using an avidin-biotin bridge. PEGNHS $(25 \mathrm{mg})$ was reacted with a lysine-biotin conjugate (biocytin) at a 1:2 molar ratio in $50 \mathrm{mM}$ sodium bicarbonate $(\mathrm{pH} 8.5)$ for $2 \mathrm{~h}$. SLe ${ }^{\mathrm{X}}$-biotin $(500 \mu \mathrm{g}$; Glycotech, Gaithersburg, Maryland) was reacted with avidin $\left(10-15\right.$ units $\left.\mathrm{mg}^{-1}\right)$ at a ratio of 2 units avidin per mole of SLe ${ }^{\mathrm{X}}$-biotin in $50 \mathrm{mM}$ sodium bicarbonate $(\mathrm{pH} 8.5)$ for $2 \mathrm{~h}$. The reaction mixtures were then combined to allow further conjugation of avidin and biotin, thereby linking acryloyl-PEG-NHS-lysinebiotin to avidin-biotin-SLe ${ }^{\mathrm{X}}$.

\section{Synthesis of Bilayered PEG Copolymer Hydrogels}

Hydrogels were formed by first dissolving $0.2 \mathrm{~g} \mathrm{ml}^{-1}$ PEG diacrylate in $10 \mathrm{mM}$ HEPES buffered saline (HBS, pH 7.4); the polymer solution was then filter sterilized using a $0.22 \mu \mathrm{m}$ filter (Gelman Sciences, Ann Arbor, MI). The photoinitiator 2,2-dimethoxy-2phenyl acetophenone in $N$-vinylpyrrolidinone (300 mg $\mathrm{ml}^{-1}$ ) was added at $10 \mu \mathrm{ml}^{-1}$ polymer solution. This 
mixture was injected between rectangular glass plates separated by $0.5 \mathrm{~mm}$ spacers and polymerized under UV light $\left(365 \mathrm{~nm}, 10 \mathrm{~mW} \mathrm{~cm}{ }^{-2}\right)$ for $30 \mathrm{~s}$. The top plate was removed and the hydrogel surface rinsed with sterile PBS. A second layer, consisting of $5 \mu \mathrm{mol} \mathrm{ml}^{-1}$ of either acryloyl-PEG-peptide or acryloyl-PEG-SLe ${ }^{\mathrm{X}}$ in HBS and $10 \mu \mathrm{ml}^{-1}$ 2,2-dimethoxy2-phenyl acetophenone in $N$-vinylpyrrolidinone was then layered on top of the PEG diacrylate base gel, the upper glass plate replaced, and the second layer photopolymerized by exposure to UV light $(365 \mathrm{~nm}$, $10 \mathrm{~mW} \mathrm{~cm}^{-2}$ ) for $1 \mathrm{~min}$.

\section{Cell Maintenance}

JURKAT cells (human T-lymphocytes; ATCC, Manassas, VA) were maintained in RPMI-1640 prepared with $10 \%$ fetal bovine serum (FBS; BioWhitaker, Walkersville, MD), $2 \mathrm{mM}$ L-glutamine, 1 unit $\mathrm{ml}^{-1}$ penicillin, and $100 \mathrm{mg}^{-1}$ streptomycin (GPS). 300.19/ E cells (mouse pre-B lymphoblast; ATCC, Manassas, VA) were sustained in RPMI-1640 prepared with $10 \%$ FBS, $1 \%$ GPS, and $0.1 \mathrm{mM}$ 2-mercaptoethanol. Cells were maintained at $37^{\circ} \mathrm{C}$ in a $5 \% \mathrm{CO}_{2}$ environment.

\section{Cell Adhesion and Rolling on Adhesive PEG Gels}

Flow assays were performed using a circular parallel plate flow chamber (Glycotech, Gaithersburg, MD) mounted on the stage of a Zeiss Axiovert 135 microscope (Carl Zeiss Inc., Thornwood, NY). The chamber was placed on top of photopolymerized PEG copolymer hydrogels and vacuum sealed to the surface using a portable vacuum pump (Fisher Scientific, Pittsburgh, PA) as shown in Fig. 1. Cell suspensions were drawn through the flow field $(1 \mathrm{~cm}$ path width, 0.01 in thickness) using a programmable syringe pump (BS8000 Multi-Phaser ${ }^{\mathrm{TM}}$ Programmable Syringe Pump, Braintree Scientific Inc., Braintree, MA) at varying flow rates corresponding to a shear stress range of 3.535 dynes $\mathrm{cm}^{-2}$, which is comparable to in vivo shear rates. Cellular interactions with the hydrogels were monitored using a Nikon CoolPix 5000 camera (Nikon Inc., Melville, NY) and transferred to videotape for further analysis.

\section{Cation Dependent Binding}

JURKAT cells were treated with $2 \mathrm{mM}$ magnesium $\left(\mathrm{Mg}^{2+}\right)$, calcium $\left(\mathrm{Ca}^{2+}\right)$, or manganese $\left(\mathrm{Mn}^{2+}\right)$ or with $10 \mathrm{mM}$ EDTA and then perfused through the flow chamber and allowed to settle on the gel for $5 \mathrm{~min}$. Controls were exposed to standard formulations of RPMI-1640 containing $0.4 \mathrm{mM} \mathrm{Ca}^{2+}$ and $0.4 \mathrm{mM} \mathrm{Mg}^{2+}$. Ten fields of view were scanned to get

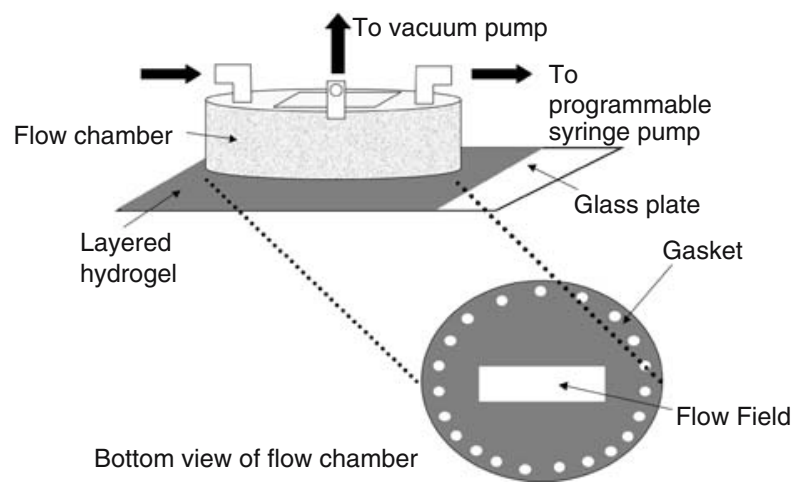

FIGURE 1. Schematic of parallel plate flow chamber system. A small pump is used to create a vacuum, sealing the chamber on the surface of the gel. Cells are then perfused over the gel surface using a programmable syringe pump.

an average number of cells per field of view. Flow rates corresponding to shear stresses of $0.5,1.0$, and $10 \mathrm{dy}-$ nes $\mathrm{cm}^{-2}$ were used to wash away unbound cells. The number of cells remaining for each shear stress was counted and averaged over several fields of view.

\section{LDV Specificity}

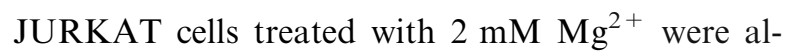
lowed to settle on the LDV gel for $5 \mathrm{~min}$ and an average number of cells per field of view was determined. Specificity was demonstrated by the addition $7 \mu \mathrm{g} \mathrm{ml}^{-1}$ of either a mouse anti-human monoclonal antibody that blocks VLA-4 binding to VCAM-1 (anti-CD49d, clone BU49; Ancell Corporation, Bayport, $\mathrm{MN}$ ) or an $\mathrm{IgG}_{1}$ isotype control (purified mouse myeloma $\mathrm{IgG}_{1}$; Invitrogen Corporation, Carlsbad, CA) at a shear stress of 0.5 dynes $\mathrm{cm}^{-2}$. The average number of cells bound per field of view was again counted to determine the amount of cells remaining bound to the surface.

Specificity was also demonstrated by the addition of a solution of either $10 \mathrm{mM}$ EDTA or $150 \mu \mathrm{M}$ Bio1211 introduced into the flow chamber under a shear stress of 0.5 dynes $\mathrm{cm}^{-2}$. An average number of cells bound to the gel under flow was determined every minute for $13 \mathrm{~min}$.

\section{Video Analysis}

Cells were allowed to settle on each gel for $5 \mathrm{~min}$. An average of 10 fields of view was scanned and the number of cells settled on the peptide gel was counted. After flow began, fields of view were scanned again and the number of cells remaining (bound to the gel) was counted. After flow was established on the SLeX gels, video was paused and the number of interacting cells was counted. The numbers were averaged over 10 fields of view for each shear stress. 


\section{Statistical Analysis}

Data were compared with two-tailed, unpaired $t$ tests; $p$-values less than 0.05 were considered to be significant.

\section{RESULTS}

\section{Synthesis of PEG Hydrogels}

PEG hydrogels were formed under UV light in the presence of a photoinitiator between two glass plates. Hydrogels $0.5 \mathrm{~mm}$ thick were formed after $30 \mathrm{~s}$ of exposure. The addition of an acryloyl-PEG-peptide derivative mixed with the photoinitiator to the surface of the hydrogels resulted in a covalently bound layer of cell adhesive moiety on the surface (Fig. 1).

\section{Quantification of Cell Adhesion and Rolling}

Cell rolling on SLeX hydrogels was quantified over a range of shear stresses, and $86.8 \pm 11.6$ cells per field of view rolled on the gel surface at 3.5 dynes $\mathrm{cm}^{-2}$ with an average rolling velocity of $141.3 \mu \mathrm{m} \mathrm{s}^{-1}$ (Fig. 2). Rolling decreased with increasing shear stress (7.0 dynes $\mathrm{cm}^{-2}$ : $15.2 \pm 3.8$ cells, average rolling velocity $232.7 \mu \mathrm{m} \mathrm{s}^{-1} ; 14$ dynes $\mathrm{cm}^{-2}: 8.2 \pm 1.9$ cells, average rolling velocity $486.8 \mu \mathrm{m} \mathrm{s}^{-1} ; 21$ dynes $\mathrm{cm}^{-2}$ : no rolling observed).

Approximately $98.5 \pm 18.6 \%$ of cells contacting hydrogel surfaces modified with Bio1211 adhered to the gel surface. In comparison, $41.5 \pm 13.4 \%$ of cells in contact with the surface of PEG-LDV, an interaction specific for the $\alpha_{4} \beta_{1}$ integrin expressed on JURKAT cells, adhered to the hydrogels and $23 \pm 8.5 \%$ of cells contacting PEG-RGDS hydrogels adhered to the gel

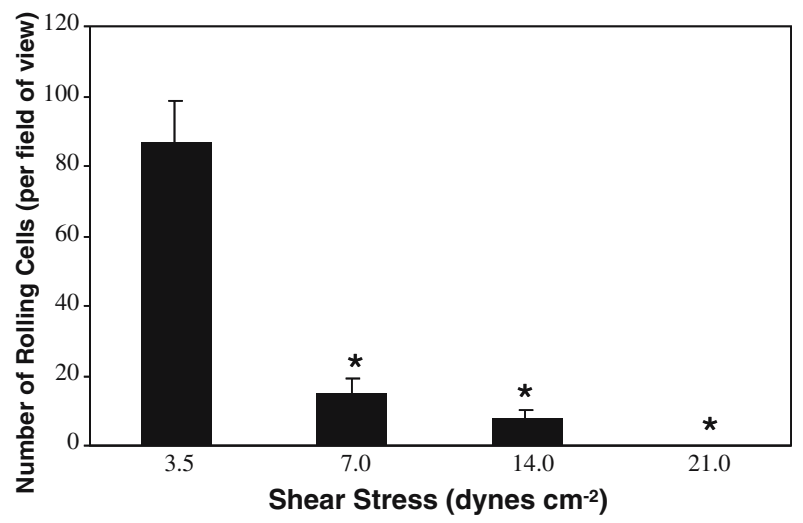

FIGURE 2. 300.19/E cells rolling on SLeX modified gel. 300.19 cells transfected with human E-selectin was perfused over a SLeX modified gel. The number of rolling cells were counted per field of view. SLeX ability to support rolling decreased as shear stress increased $\left({ }^{\star} p<0.02\right.$ as compared to shear rate of 3.5 dyne $\mathrm{cm}^{-2}$ ). surface (Fig. 3). No cells adhesion to PEG-DA or PEG-RGES hydrogels was observed; however the control LEV peptide-modified gels had $1.6 \pm 1.2 \%$ of cells contacting the surface adhere.

\section{Cation Dependant Binding}

Cation sensitivity was assessed by the addition of cations or EDTA to cell cultures prior to their exposure to PEG-LDV hydrogels. The presence of $10 \mathrm{mM}$ EDTA had the greatest inhibitory effect on binding, followed by $2 \mathrm{mM} \mathrm{Ca}^{2+} \cdot \mathrm{Mg}^{2+}$ and $\mathrm{Mn}^{2+}$ had little effect on the ability of JURKAT cells to bind LDV, and a higher number of cells exposed to both calcium and magnesium were able to bind to the gel surface than those exposed to calcium alone (Fig. 4).

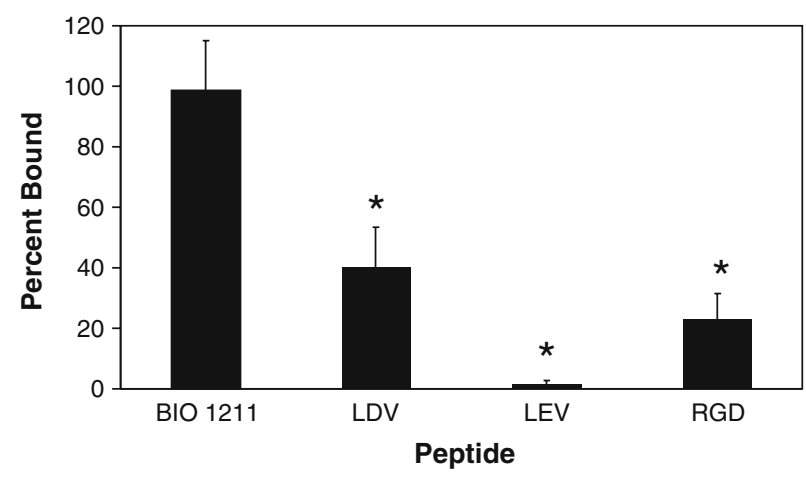

FIGURE 3. Peptide ability to bind VLA-4. JURKAT cells were allowed to settle on PEG-DA gels conjugated with different peptides at similar densities. After $5 \mathrm{~min}$, cells were subjected to a shear stress of 0.5 dynes $\mathrm{cm}^{-2}$ to remove unbound cells and the remaining cells were counted ( ${ }^{\star} p<0.02$ compared to Bio1211).

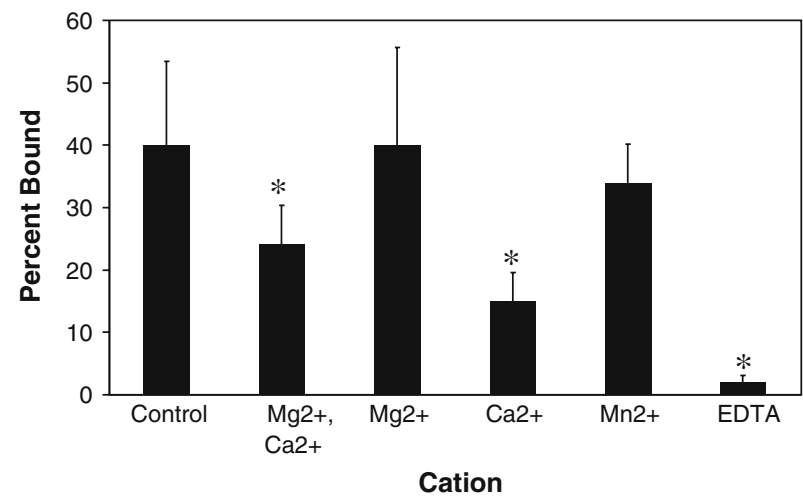

FIGURE 4. Cation dependent binding of VLA-4 to LDV peptide. JURKAT cells were incubated with $2 \mathrm{mM}$ cations or $10 \mathrm{mM}$ EDTA prior to settling on the LDV gel; controls were exposed to standard formulations of RPMI-1640 containing $0.4 \mathrm{mM} \mathrm{Ca}^{2+}$ and $0.4 \mathrm{mM} \mathrm{Mg}^{2+}$. The percentage of cells on the gel was determined based on the total number of cells before initiating a shear stress of 0.5 dynes $\mathrm{cm}^{-2}\left({ }^{\star} p<0.05\right.$ compared to Control). 


\section{LDV Specificity}

JURKAT cell binding to PEG-LDV hydrogels was reversed upon the addition of a monoclonal anti-VLA$4(3.4 \pm 2.1 \%$ bound). Cells exposed to an isotypematched control antibody were still able to adhere to the hydrogel surface $(88.8 \pm 33.4 \%$ bound $)$, demonstrating specificity of LDV for the VLA-4 integrin. The higher affinity of Bio1211 compared to the LDV peptide was also observed by the addition of unbound Bio1211 after cells were allowed to settle on PEG-LDV hydrogels (Fig. 5). Bio1211 was able to remove cells from the gel surface better than EDTA through competitive binding of VLA-4.

The influence of peptide concentration on cell adhesion was determined by varying the amounts of LDV bound to the hydrogel surface (Fig. 6). The number of cells bound to the gel increased with LDV concentration, and LDV was better able to support adhesion at lower shear stresses for all concentrations when compared to higher rates of shear.

\section{DISCUSSION}

The system of hydrophilic hydrogels modified with cell adhesion peptides implemented in this study exhibits the ability to mimic the cell adhesion cascade that occurs during the onset of inflammation in the

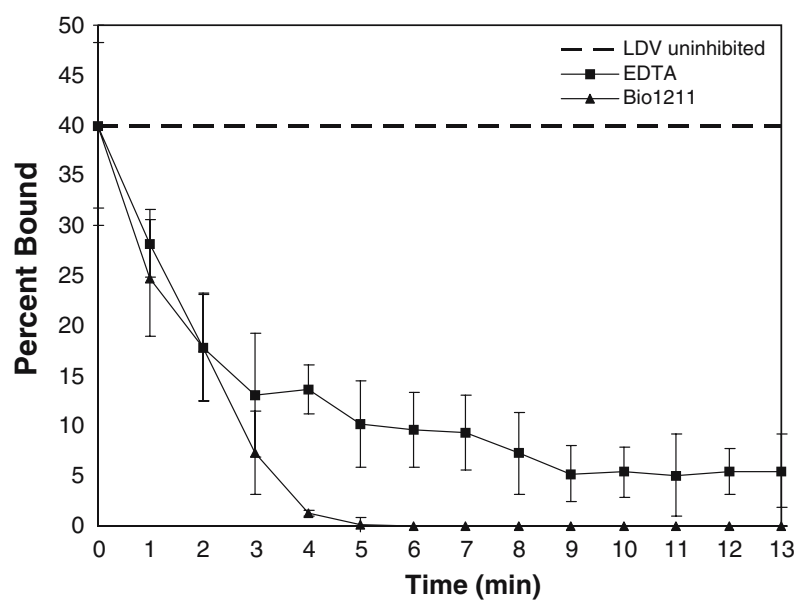

FIGURE 5. LDV Specificity for VLA-4. $10 \mathrm{mM}$ EDTA or $1.5 \mathrm{uM}$ Bio1211 was introduced into the flow chamber at a wall shear stress of 0.5 dynes $\mathrm{cm}^{-2}$ after JURKAT cells were allowed to settle on the LDV gel for $5 \mathrm{~min}$. Bio1211, which has a higher affinity for VLA-4 was able to compete the cells off the LDV modified gel surface. EDTA was not as effective as Bio1211 as cells detached more slowly and not completely. The dashed line represents the uninhibited controls, in which $40 \pm 15.2 \%$ of the cells initially exposed to the hydrogel remained bound through the duration of the experiment. Each data point represents the average percent of bound cells per 10 fields of view and error bars represent the standard deviation of the percent of bound cells within those 10 fields of view.

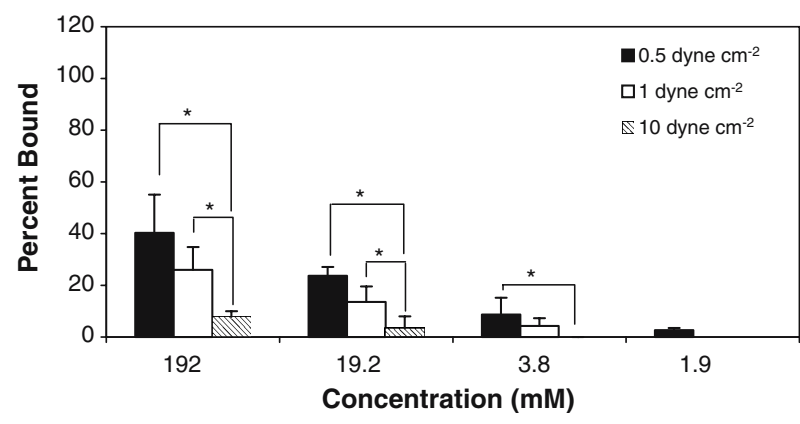

FIGURE 6. Dilution effect of LDV. The number of JURKAT cells bound to the gel decreased as the LDV peptide concentration was lowered. LDV was better able to support adhesion at lower shear stresses for all concentrations ( ${ }^{*} p<0.05$ comparing shear rates at each concentration).

vascular system. The capacity to modify hydrogels with cell adhesion molecules for the study of cellular interactions with biomaterials for drug delivery and tissue engineering is well documented. , $7,15,16,18,24-26,29$ $-31,38,39,44$ This study implements the use of these materials under physiological flow conditions to examine the mechanisms of leukocyte rolling and firm adhesion.

The formation of thin flat PEG diacrylate hydrogels for use with a parallel plate flow chamber improves upon earlier systems that utilize hydrophobic surfaces with adsorbed cell adhesion molecules. The highly crosslinked structure of swollen PEG networks have water content similar to native vessels, and covalent incorporation of cell adhesive peptides guarantees control of concentration and allows for patterning of one or more adhesion sequences on the gel surface. ${ }^{23}$ This system is based on a flexible substrate with tunable stiffness, the properties of which can be exploited to examine the responses of different cell types in microenvironments that mimic native tissues in various states of development, remodeling, regeneration, and disease. It has been suggested that the differentiation of cellular function and response could depend significantly on matrix elasticity, ${ }^{8,14,45}$ and varying the polymer composition or concentration in the hydrogel can alter the permeability and mechanical properties, ${ }^{36}$ simulating a range of biologically relevant conditions. In addition, the local mobility of adhesive ligands in the solvated hydrogel system should be considerably better than on solid substrates, allowing more variable orientations which could contribute to a greater fraction of accessible ligands available to receptors on the cell surface.

Leukocyte cell adhesion to the surfaces of modified PEG-DA hydrogels was highly specific, reversible, and sensitive to ligand site density and affinity, demonstrating the efficacy of the system to mimic the events leading to the firm adhesion of immune cells on 
activated endothelium. The slow rolling of 300.19/E cells on the surfaces of PEG-SLe ${ }^{\mathrm{X}}$ hydrogels confirms the integration of $\mathrm{SLe}^{\mathrm{X}}$ into the system through the use of an avidin-biotin linkage, which did not disrupt the active binding site of the carbohydrate. Incorporation of the RGD and LDV peptides encouraged firm cell adhesion to the materials surface under shear in a concentration dependant manner, and cells remained adherent throughout the duration of the flow experiment. These results illustrate that this method of studying leukocyte adhesion succeeds in mimicking the interactions seen on the in vivo vascular wall under shear. With further optimization, such as incorporation of signaling molecules, this system using of PEG gels can improve insight into the mechanisms of rolling and firm cell adhesion at sites of active vascular disease.

\section{CONCLUSIONS}

The covalent modification of PEG hydrogel surfaces with cell adhesive peptides was accomplished in continuous layers of adhesive regions. These materials encouraged vascular cell adhesion through both transient interactions with selectin molecules and firm binding via integrins. The system presented here to expose adhesive hydrogels to cells under flow conditions represents a method to study cell-material interactions in environments that closely mimic in vivo environments.

\section{ACKNOWLEDGMENTS}

The authors would like to thank Marcella Estrella (Rice University) for technical assistance. Research funding was provided by the National Institutes of Health [NIH R01 HL070537], the Rice University Alliance for Graduate Education and the Professoriate (AGEP) [NSF Cooperative Agreement No. HRD9817555], and the Rice University Integrative Graduate Education and Research Traineeship (IGERT) [NSF Grant 0114264].

\section{REFERENCES}

\footnotetext{
${ }^{1}$ Bhatia, S. K., M. R. King, and D. A. Hammer The state diagram for cell adhesion mediated by two receptors. Biophys. J. 84:2671-2690, 2003.

${ }^{2}$ Bhatia, S. K., J. S. Swers, R. T. Camphausen, K. D. Wittrup, and D. A. Hammer Rolling adhesion kinematics of yeast engineered to express selectins. Biotechnol. Prog. 19:1033-1037, 2003.

${ }^{3}$ Blanks, J. E., T. Moll, R. Eytner, and D. Vestweber Stimulation of P-selectin glycoprotein ligand-1 on mouse
}

neutrophils activates beta 2-integrin mediated cell attachment to ICAM-1. Eur. J. Immunol. 28:433-443, 1998.

${ }^{4}$ Bryant, S. J. and K. S. Anseth The effects of scaffold thickness on tissue engineered cartilage in photocrosslinked poly(ethylene oxide) hydrogels. Biomaterials 22:619-626, 2001.

${ }^{5}$ Chen, L. L., A. Whitty, R. R. Lobb, S. P. Adams, and R. B. Pepinsky Multiple activation states of integrin alpha4betal detected through their different affinities for a small molecule ligand. J. Biol. Chem. 274(19):13167-13175, 1999. ${ }^{6}$ Chigaev, A., G. Zwartz, S. W. Graves, D. C. Dwyer, H. Tsuji, T. D. Foutz, B. S. Edwards, E. R. Prossnitz, R. S. Larson, and L. A. Sklar Alpha4betal integrin affinity changes govern cell adhesion. J. Biol. Chem. 278(40):38174-38182, 2003.

${ }^{7}$ DeLong, S. A., J. J. Moon, and J. L. West Covalently immobilized gradients of bFGF on hydrogel scaffolds for directed cell migration. Biomaterials 26:3227-3234, 2005.

${ }^{8}$ Discher, D. E., P. Janmey, and Y. Wang Tissue cells feel and respond to the stiffness of their substrate. Science 310:1139-1143, 2005.

${ }^{9}$ Dustin, M. L., R. Rothlein, A. K. Bhan, C. A. Dinarello, and T. A. Springer Induction by IL 1 and interferongamma: Tissue distribution, biochemistry, and function of a natural adherence molecule (ICAM-1). J. Immunol. 137:245-254, 1986

${ }^{10}$ Elices, M. J., L. Osborn, Y. Takada, C. Crouse, S. Luhowskyj, M. E. Hemler, and R. R. Lobb VCAM-1 on activated endothelium interacts with the leukocyte integrin VLA-4 at a site distinct from the VLA-4/fibronectin binding site. Cell 60(4):577-584, 1990

${ }^{11}$ Eniola, A. O., P. J. Willcox, and D. A. Hammer Interplay between rolling and firm adhesion elucidated with a cellfree system engineered with two distinct receptor-ligand pairs. Biophys. J. 85:2720-2731, 2003.

${ }^{12}$ Evangelista, V., S. Manarini, R. Sideri, S. Rotondo, N. Martelli, A. Piccoli, L. Totani, P. Piccardoni, D. Vestweber, G. de Gaetano, and C. Cerletti Platelet/polymorphonuclear leukocyte interaction: P-selectin triggers proteintyrosine phosphorylation-dependent CD11b/CD18 adhesion: role of PSGL-1 as a signaling molecule. Blood 93:876885,1999

${ }^{13}$ Galley, H. F., M. G. Blaylock, A. M. Dubbels, and N. R. Webster Variability in E-selectin expression, mRNA levels and sE-selectin release between endothelial cell lines and primary endothelial cells. Cell Biol. Int. 24:91-99, 2000.

${ }^{14}$ Georges, P. C. and P. A. Janmey Cell type-specific response to growth on soft materials. J. Appl. Physiol. 98:1547-1553, 2005.

${ }^{15}$ Gobin, A. S. and J. L. West Cell migration through defined, synthetic ECM analogs. Faseb. J. 16:751-753, 2002.

${ }^{16}$ Gobin, A. S. and J. L. West Val-ala-pro-gly, an elastinderived non-integrin ligand: Smooth muscle cell adhesion and specificity. J. Biomed. Mater. Res. A. 67:255-259, 2003.

${ }^{17}$ Goetz, D. J., D. M. Greif, H. Ding, R. T. Camphausen, S. Howes, K. M. Comess, K. R. Snapp, G. S. Kansas, and F. $\mathrm{W}$. Luscinskas Isolated P-selectin glycoprotein ligand-1 dynamic adhesion to $\mathrm{P}$ - and E-selectin. J. Cell Biol. 137:509-519, 1997.

${ }^{18}$ Gonzalez, A. L., A. S. Gobin, J. L. West, L. V. McIntire, and C.W. Smith Integrin interactions with immobilized peptides in polyethylene glycol diacrylate hydrogels. Tissue Eng. 10:1775-1786, 2004.

${ }^{19}$ Gopalan, P. K., C. W. Smith, H. Lu, E. L. Berg, L. V. McIntire, and S. I. Simon Neutrophil CD18-dependent 
arrest on intercellular adhesion molecule 1 (ICAM-1) in shear flow can be activated through L-selectin. J. Immunol. 158:367-375, 1997.

${ }^{20}$ Graham, N. B. Hydrogels: Their future, Part I. Med. Device Technol. 9:18-22, 1998.

${ }^{21}$ Graham, N. B. Hydrogels: Their future, Part II. Med. Device Technol. 9:22-25, 1998.

${ }^{22}$ Griffith, L. G. Emerging design principles in biomaterials and scaffolds for tissue engineering. Ann. NY Acad. Sci. 961:83-95, 2002.

${ }^{23}$ Hahn, M. S., L. J. Taite, J. J. Moon, M. C. Rowland, K. A. Ruffino, and J. L. West Photolithographic patterning of polyethylene glycol hydrogels. Biomaterials 27:2519-2524, 2006.

${ }^{24}$ Hern, D. L. and J. A. Hubbell Incorporation of adhesion peptides into nonadhesive hydrogels useful for tissue resurfacing. J. Biomed. Mater. Res. 39:266-276, 1998.

${ }^{25}$ Hill-West, J. L., S. M. Chowdhury, M. J. Slepian, and J. A. Hubbell Inhibition of thrombosis and intimal thickening by in situ photopolymerization of thin hydrogel barriers. Proc. Natl. Acad. Sci. USA 91:5967-5971, 1994.

${ }^{26}$ Hubbell, J. A. Bioactive biomaterials. Curr. Opin. Biotechnol. 10:123-129, 1999.

${ }^{27}$ Lawrence, M. B. and T. A. Springer Neutrophils roll on Eselectin. J. Immunol. 151:6338-6346, 1993.

${ }^{28}$ Lawrence, M. B., L. V. McIntire, and S. G. Eskin Effect of flow on polymorphonuclear leukocyte/endothelial cell adhesion. Blood 70:1284-1290, 1987.

${ }^{29}$ Lin-Gibson, S., S. Bencherif, J. A. Cooper, S. J. Wetzel, J. M. Antonucci, B. M. Vogel, F. Horkay, and N. R. Washburn Synthesis and characterization of PEG dimethacrylates and their hydrogels. Biomacromolecules 5:1280 1287, 2004.

${ }^{30}$ Mann, B. K., R. H. Schmedlen, and J. L. West TetheredTGF-beta increases extracellular matrix production of vascular smooth muscle cells. Biomaterials 22:439-444, 2001.

${ }^{31}$ Mann, B. K., A. T. Tsai, T. Scott-Burden, and J. L. West Modification of surfaces with cell adhesion peptides alters extracellular matrix deposition. Biomaterials 20:2281-2286, 1999.

${ }^{32}$ Mougin, K., A. S. Ham, M. B. Lawrence, E. J. Fernandez, and A. C. Hillier Construction of a tethered poly(ethylene glycol) surface gradient for studies of cell adhesion kinetics. Langmuir 21:4809-4812, 2005.

${ }^{33}$ Mougin, K., M. B. Lawrence, E. J. Fernandez, and A. C. Hillier Construction of cell-resistant surfaces by immobilization of poly(ethylene glycol) on gold. Langmuir 20:43024305, 2004.
${ }^{34}$ Munro, J. M. Endothelial-leukocyte adhesive interactions in inflammatory diseases. Eur. Heart J. 14:72-77, 1993.

${ }^{35}$ Munro, J. M., S. K. Lo, C. Corless, M. J. Robertson, N. C. Lee, R. L. Barnhill, D. S. Weinberg, and M. P. Bevilacqua Expression of sialyl-Lewis $\mathrm{X}$, an E-selectin ligand, in inflammation, immune processes, and lymphoid tissues. Am. J. Pathol. 141:1397-1408, 1992.

${ }^{36}$ Nguyen, K. T. and J. L. West Photopolymerizable hydrogels for tissue engineering applications. Biomaterials 23:4307-4314, 2002.

${ }^{37}$ Patel, K. D., K. L. Moore, M. U. Nollert, and R. P. McEver Neutrophils use both shared and distinct mechanisms to adhere to selectins under static and flow conditions. J. Clin. Invest. 96:1887-1896, 1995.

${ }^{38}$ Peppas, N. A. Hydrogels in Medicine and Pharmacy, 1. CRC Press, Boca Raton, FL. 1986.

${ }^{39}$ Qiu, B., S. Stefanos, J. Ma, A. Lalloo, B. A. Perry, M. J. Leibowitz, P. J. Sinko, and S. Stein A hydrogel prepared by in situ cross-linking of a thiol-containing poly(ethylene glycol)-based copolymer: A new biomaterial for protein drug delivery. Biomaterials 24:11-18, 2003.

${ }^{40}$ Reinhardt, P. H., J. F. Elliott, and P. Kubes Neutrophils can adhere via alpha4betal-integrin under flow conditions. Blood 89:3837-3846, 1997.

${ }^{41}$ Rosen, S. D. and C. R. Bertozzi The selectins and their ligands. Curr. Opin. Cell Biol. 6:663-673, 1994.

${ }^{42}$ Simon, S. I., Y. Hu, D. Vestweber, and C. W. Smith Neutrophil tethering on E-selectin activates beta 2 integrin binding to ICAM-1 through a mitogen-activated protein kinase signal transduction pathway. J. Immunol. 164:43484358, 2000.

${ }^{43}$ Springer, T. A. Traffic signals for lymphocyte recirculation and leukocyte emigration: The multistep paradigm. Cell 76:301-314, 1994.

${ }^{44}$ West, J. L. and J. A. Hubbell Comparison of covalently and physically cross-linked polyethylene glycol-based hydrogels for the prevention of postoperative adhesions in a rat model. Biomaterials 16:1153-1156, 1995.

${ }^{45}$ Yeung, T., P. C. Georges, L. A. Flanagan, B. Marg, M. Ortiz, M. Funaki, N. Zahir, W. Ming, V. Weaver, and P. A. Janmey Effects of substrate stiffness on cell morphology, cytoskeletal structure, and adhesion. Cell Motil. Cytoskeleton 60:24-34, 2005. 